\title{
Electrical Tandem Roller (ETR) Media for 4C Capabilities Based Stem Learning Elementary Schools
}

\author{
Cahyana $^{1 *}$, Ghullam Hamdu ${ }^{2}$, Dindin Abdul Muiz Lidinillah ${ }^{3}$, Seni Apriliya ${ }^{4}$
}

1234 Program Studi Pendidikan Guru Sekolah Dasar, Universitas Pendidikan Indonesia Kampus Tasikmalaya, Indonesia

\author{
A RTICLEINFO \\ Article history: \\ Received 18 March 2020 \\ Received in revised form \\ 30 April 2020 \\ Accepted 5 May 2020 \\ Available online 15 May \\ 2020 \\ kata kunci: \\ media; STEM; kemampuan \\ $4 \mathrm{C}$. \\ keywords: \\ Media; STEM; 4 C Capability
}

\begin{abstract}
A B S T R A K
Media pembelajaran sangat bermanfaat untuk membantu siswa memahami konsep materi pembelajaran yang diberikan. Penggunaan media pembelajaran inovatif masih terbatas pada proses pembelajaran khususnya pembelajaran tematik. Media pembelajaran inovatif tematik secara lebih khusus dikembangkan dengan pembelajaran berbasis STEM berdasarkan kemampuan 4C yaitu Media Electrical Tandem Roller (ETR). Pengembangan media dilakukan dengan Metode Focus General Discussion (FGD) dengan pendekatan kualitatif. Proses pelaksanaan tahapan $F G D$ ini melibatkan tim pengembang perangkat pembelajaran STEM yang bertujuan untuk memvalidasi media yang dihasilkan tanpa melalui uji coba secara lapangan. Media ETR berdasakan kemampuan 4C di sekolah dasar telah dihasilkan untuk pembelajaran STEM. Dengan adanya media pembelajaran inovatif ini diharapkan dapat digunakan khususnya bagi guru dalam pembelajaran tematik di sekolah dasar.
\end{abstract}

\section{A B S T R A C T}

Learning media is very useful to help students understand the concepts of learning material provided. The use of innovative learning media is still limited to the learning process, especially thematic learning. Thematic innovative learning media is more specifically developed with STEM-based learning based on 4C capabilities, namely the Media Electrical Tandem Roller (ETR). Media development is carried out using the Focus General Discussion (FGD) Method with a qualitative approach. The process of implementing this FGD stage involved the development team of STEM learning tools that aims to validate the media produced without going through field trials. ETR media based on the ability of 4C in elementary schools has been produced for STEM learning. This innovative learning media is expected to be used, especially for teachers in thematic learning in elementary schools.

\section{Introduction}

The 2013 curriculum has specific characteristics. In the Minister of Education and Culture Regulation No. 67 of 2013 concerns the content of learning in the 2013 curriculum, namely the implementation of the 2013 curriculum at the Elementary School/Madrasah Ibtidaiyah, learning is carried out through thematic-integrated from the first grade to the sixth grade. However, for some subjects, for example, Religious Education and Moral are excluded from integrated thematic learning. Thematic learning is designed to improve optimal and maximum learning outcomes by transporting the experiences of students who have a network of various aspects of their lives and experiences (Kadir and Asrohah, 2015). Thematic learning is done by combining several subjects to provide meaningful experiences for students. The combination of these subjects is then bound by a theme. The theme is the main thoughts or ideas that are the subject of conversation. The theme will be the first step as the main focus in planning learning (Majid, 2014). Besides being the main focus in planning learning, themes are also used in the learning process.

The learning process in thematic learning can provide opportunities for students to learn and explore various types of learning between integrated interdisciplinary sciences. One of the learning done by integrating several disciplines is STEM learning (Science, Technology, Engineering, and Mathematics) (Cunningham, 2018). STEM learning is defined as the combination of various disciplines, namely Science, Technology, Engineering, and Mathematics. STEM education is promoted in various countries to prepare their citizens to understand STEM and have multidisciplinary abilities as a support in modern life (Pimthong and Williams, 2018). The implementation at school, students need to apply science, technology, engineering, and mathematics in learning in the form of rigorous academic

Copyright (C) Universitas Pendidikan Ganesha. All rights reserved.

1 Corresponding author.

E-mail addresses: cahyana389@student.upi.edu (cahyana)1, ghullamh2012@upi.edu (ghullam)22,dindin_a_muiz@upi.edu(dindin)³,

seni_apriliya@upi.edu (seni) ${ }^{4}$ 
concepts combined with real-world learning. It allows the development of STEM literacy toward these capabilities so that they can complement each other (Torlakson, 2014).

Increasing the ability of young generation to deal with the various demands of $21^{\text {st }}$ century life that are so complex and need to be prepared from the various exist challenges. Educating this generation of scientific literacy is one of the core goals of STEM learning (Shaugnessy in English \& King, 2015). STEM learning provides opportunities for students to show students the concepts, principles, and techniques of science, technology, engineering, and mathematics used in an integrated manner in the development of products, processes and systems used in students' daily lives (Firman, 2015). STEM learning can be developed in elementary schools because it can facilitate students in implementing the $21^{\text {st }}$ century skills.

The $21^{\text {st }}$ century learning skills are important parts to be taught to students based on competencies that must be achieved by students. The competence consists of the skills of ways of thinking, ways of working, tools of working, and living in the world (Griffin and McGaw, 2012). The term is part of the educational dimension specifically the skill dimension. The provided skills dimension is a way to achieve these skills, namely ways of thinking and ways of working. Ways of thinking skills means being able to think critically (critical thinking) and thinking creatively (creative), while ways of working means being able to work collaboratively (collaboration) and communicate (communication). This ability is later abbreviated to 4c (critical thinking, creative, collaboration, and Communication) (Griffin \& Care, 2015). The 4C ability is very relevant to be applied to students in the 21st century education era because it is able to make students more active in the learning process. $4 \mathrm{C}$ capability is also contained in the 2013 curriculum which requires students to be able to think critically, creatively, collaborate, and communicate (Binkley in Griffin \& McGaw, 2012). In the 2013 curriculum there is coherence between the implementation of 2013 curriculum learning and STEMbased learning that is thematic so that it can be integrated. With this coherence, thematic learning will be carried out well. Thematic learning requires the availability of supporting learning resources. Learning resources in question are certain tools or materials that can support the learning process. There is a need for supporting learning facilities to get the quality of understanding and perfect learning outcomes. The

Learning media is an intermediary or delivery message from the sender to the recipient who has the motivation to learn so that it is expected to obtain satisfying learning outcomes (Mudlofir and Rusydiyah, 2017). Learning media is very useful to help students in understanding the concept of a given learning material and it can anticipate the occurrence of learning misconceptions. The use of learning media can meet the learning component so that the learning process is conducted maximally as well as the learning objectives will be conveyed in full (Pambudi, 2018). As a study has been done before, learning media can improve students' understanding in concept mastery of material provided by the teacher (Wijayanti, 2018).

However, the use of innovative learning media in general has not been developed optimally. The existing learning media are still very limited when it is used during the implementation of the learning process and they are generally not very specific for learning implementation with certain methods. Some previous existed instructional media seem ordinary and lack of student attention and interest during the learning process. Learning media still look conventional and there are still many limitations in their use, especially media in the 2013 thematic curriculum learning. The use of instructional media in primary schools in general is still limited to the use of teachers' books and students' books and practical tools used in classrooms such as pictures, chairs, and desk, so students face difficulty in connecting a concept, especially in thematic learning (Meilinda, 2017). The availability of instructional for thematic learning is inadequate and the teacher has limited time to develop media. The teacher's initiative to develop learning media is not yet used. The teacher's interest in developing learning media still seems less enthusiastic. Some teachers said that they found it difficult to allocate time because there were some preoccupations with the large amount of school work that must be done. This activity prevents the teacher from discussing to conduct a study regarding the development of instructional media that becomes difficult to be implemented. The existing learning media also do not support $21^{\text {st }}$ century learning that requires students to have $4 \mathrm{C}$ abilities. Therefore, innovation is needed in the form of learning media development that supports thematic learning in the 2013 curriculum and $21^{\text {st }}$ century learning (Meilinda, 2017).

The objective of this study was to develop innovative learning media that can support thematic learning integrated with STEM learning. This innovative media is called "Electrical Tandem Roller (ETR)". Learning media were made concretely in the form of three-dimensional media or it is also called Mock-up media. Mock-ups are imitations of actual objects where deliberately selected important parts to be made as simple as possible so that they are easy to learn (Sanaky, 2011; Hernawan, 2007). 
The use of instructional media in this case was adjusted to the basic competency listed in the 2013 curriculum related to the selected class level, namely the fifith grade elementary school.

\section{Method}

Focus Group Discussion (FGD) research method was conducted to develop this innovative media which applied a qualitative approach. The FGD method is a method and technique for collecting qualitative data in which a group of people discuss a particular problem or topic guided by a facilitator or moderator (Indrizal, 2014). FGD involves people with different backgrounds or experiences to discuss interesting things and include qualitative research that addresses questions based on their perceptions, attitudes, beliefs, and ideas involved in the FGD (Baral, S et al, 2016)

The purpose of using the FGD method in this study was to explore and obtain information related to the ETR media in depth based data interaction from the results of group discussions, so it can increase the depth of information from various aspects regarding the development of STEM learning media that will be created (Bareen L. R., 2006). The main strength of the FGD method is on providing deeper, more informative, and more valuable data than other methods (Afiyanti, 2008).

This FGD process involved another research team that was still in the research umbrella related to the development of 7 STEM learning tools. Each team member examined the development of learning designs, Student Worksheets, teaching materials, innovative media, assessment in written test questions, performance assessments, and videos on learning implementation. The data were obtained in the form of qualitative data. Qualitative data is the data description of the discussion results that were obtained from the FGD results step by step (Agung, 2014). In addition, interviews are also used to identify the use of instructional media in schools. Interviews were conducted with the sixth grade teacher at SDN Mancogeh (Elementary School) in Tasikmalaya City and SDN 3 Manonjaya in Tasikmalaya District. The stages of the FGD implementation process were adopted from Glynn et.al (Omar, 2018) as follows.

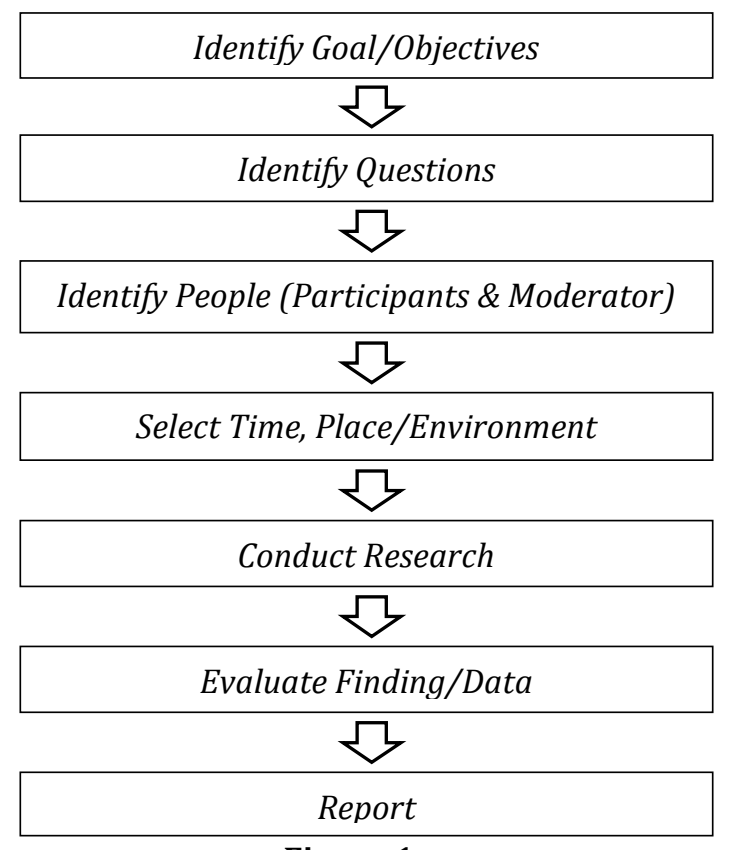

Figure 1

Steps of Focus General Discussion (FGD)

Identify goal/objective was the first stage in the FGD process. At this stage, the objectives of the study were identified. The second step was identifying questions. At this stage, the researcher identified questions related to the study and these questions must be solved. The third step was to identify people. At this stage, the identification of people who would contribute to the FGD was identified, such as the moderator, note taker, and the FGD participants themselves. The fourth step was at selecting time, place/environment. At this stage, the researcher determined the right time to carry out the FGD so that the FGD could be conducted properly. The researcher made a schedule for implementing the FGD so that the FGD could be well ordered and structured. The fifth stage was at conducting research. At this stage the researcher conducted research. The sixth step was on evaluating 
finding/data. At this stage, the researcher evaluated the findings or data that had been obtained to be used as a research report. The last stage was the report. At this stage the researcher reported the results of the research.

\section{Result and Discussion}

Based on the results of interviews, it was found that instructional media was very useful and helps teachers in the learning process. In addition, the thematic learning media was very important because it was easy to convey the material taught to students comprehensively without any visible separation of learning material. Therefore, learning media was very important to be used in the learning process. However, based on interviews, it was also found that STEM learning was still rarely implemented by teachers due to the limitation of learning facilities and infrastructure including learning media. For this reason, innovation is needed in developing learning media that supports STEM learning. The existence of learning media can facilitate students in understanding the concepts of each subject. The availability of learning media is still limited, especially in thematic learning that is integrated with STEM learning, it has chance to conduct the process of designing learning media specifically for learning. The learning media is the "Electrical Tandem Roller (ETR)" that acts as a solution to solve problems. The ETR media was obtained based on the results of the FGD which was conducted in stages by the researchers with the STEM research team.

ETR media is a media that has form like a tool for repairing the road (Tandem Roller). This media is a type of mock-up media that is a media imitation of existing objects and it can not be brought into classroom as learning media. The existing Tandem Roller is then developed and made as learning media. Although this is an imitation object, ETR media has differences. Researchers make innovations in the form of adding a series of lights and change the motion of the media to make it more interesting. Innovation of learning media development focused on the learning needs in elementary schools, namely the thematic learning media based on STEM to achieve the overall 4C capability. This STEM learning is very suitable to be applied in the current elementary school curriculum, the 2013 curriculum, because the learning is based on the concept of educating students in four fields by integrating and applying in the real world context (Nurlenasari, Lidinillah, Nugraha, \& Hamdu, 2019). The design of media development paid attention to the design principle) procedurally related to the design activities to conduct media development. The elaboration of the design principles in the process of developing this learning media started from determining the model and it is equipped with the intended purpose of making the learning media. The context and characteristics of the media become the focus. The characteristics of the media were adapted from several things in the form of adjustments to the Basic Competence (KD) in the 2013 primary school curriculum chosen especially in the sixth grade. The selected basic competencies were in Natural Sciences, Mathematics, and Indonesian subjects. The selected basic competencies are as follows.

Natural Science

$3.4 \quad$ Identifying simple electrical components and their functions electrical circuits.

4.4. Performing simple electrical circuit experiments in series and parallel.

\section{Figure 2}

Table of Natural Science Basic Competency

Mathematics

\begin{tabular}{|c|l|}
\hline 3.3. & $\begin{array}{l}\text { Explaining the comparison of two different quantities (speed as the ratio of distance to } \\
\text { time, discharge as a comparison) }\end{array}$ \\
\hline 4.3 & Solving problems related to the comparison of two different quantities (speed, discharge).
\end{tabular}

Figure 3

Table of Mathematics Basic Competency

Indonesian

3.2 Exploring the contents of explanatory text (explanation) scientific that is heard and read.

4.2 Presenting the results of extracting information from explanatory texts (explanations) scientific verbally, written, and visual by using standard vocabulary and effective sentence

Figure 4

Table of Indonesian Basic Competency 
The implementation of ETR media design in learning followed the STEM learning path to achieve 4C capabilities. The creation of ETR media used several tools and materials that were tailored to the needs of the product. The learning media design was made to prepare for the FGD process with groups and experts. The FGD was conducted gradually to obtain deep information and optimal results regarding the learning media especially the ETR media.

The first FGD discussed the design of learning media related to the basic competency in the sixth grade elementary schools. In the first FGD process, the results of ideas related to the media were ETR media. The next FGD discussed the development of ETR. The discussion started from the KD that underlies the media creation to the results or the final product of the media. After conducting the FGD, the ETR media was made, although there were still many shortcomings such as the non-progress of the media.

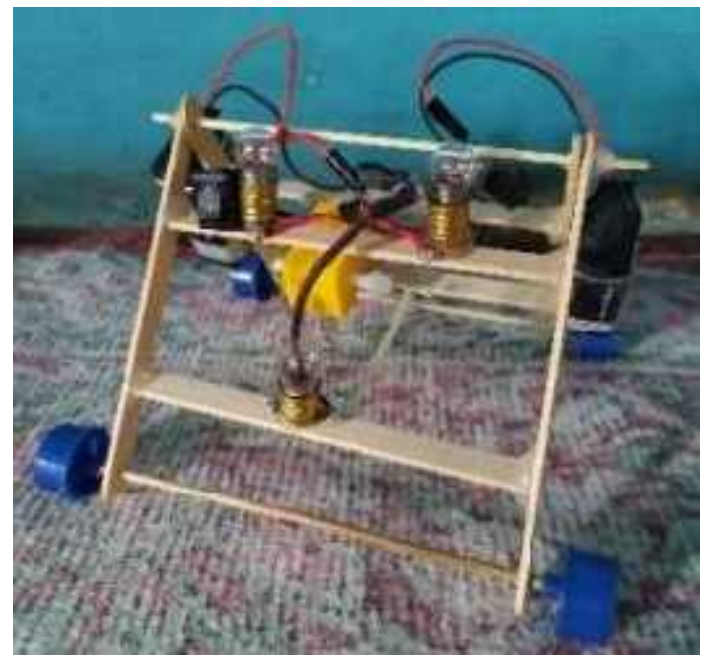

Figure 5

Pre-design of ETR media

The ETR media had changed and improved. These improvements were the result of FGD that had been conducted with groups and experts. The first improvement was made to the media tire. Media tires were so small and there was an imbalance between the media body and the tire so that the tires changed.

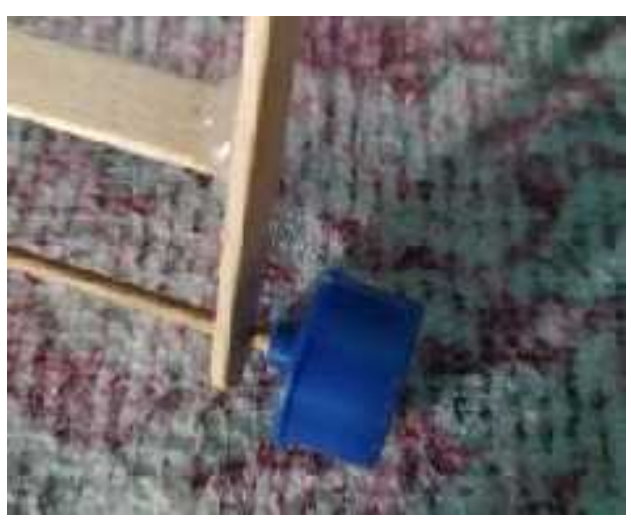

Figure 6

The first tire of ETR media

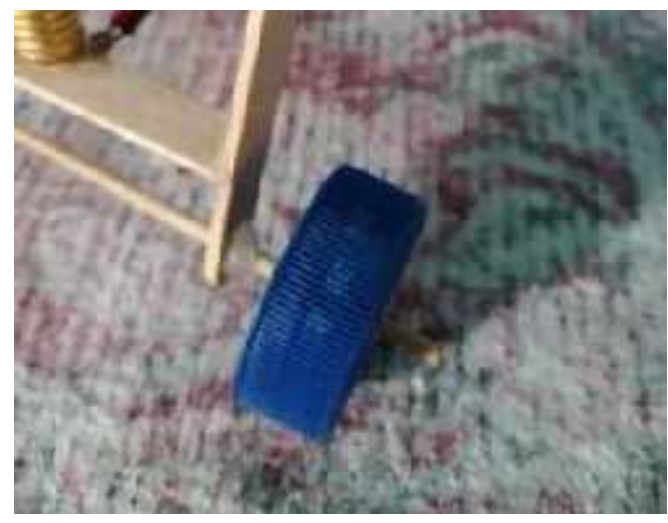

Figure 7

The tire of ETR media has changed

After the tire was replaced, there were still shortcomings. Tires of the media were slippery so that the frictional force was very small. For this reason, repairs were carried out by coating the tire using wound tape. As a result, the tires became slippery and the friction forces became larger. 


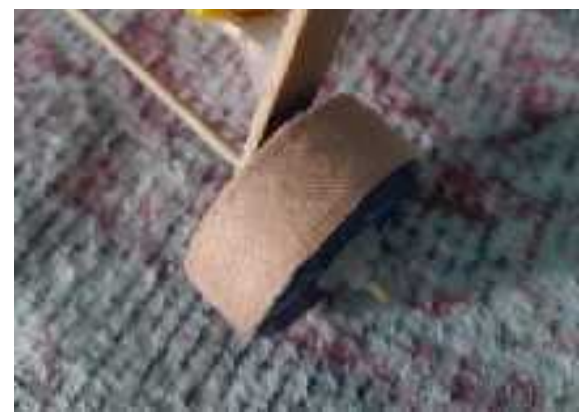

Figure 8

The tire of ETR media has coated

Improvements were also made to the electrical circuit that were installed in the front of the media. Repairs were made to the wiring and lighting to produce a good and functioning circuit so that the lights can be lit.

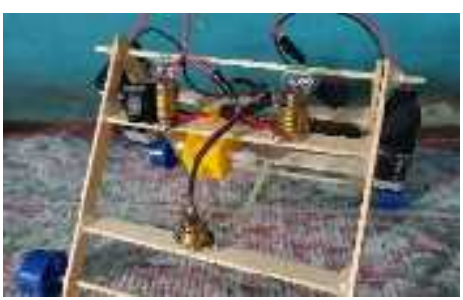

Figure 9

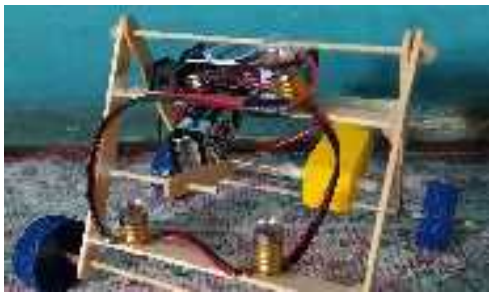

Figure 10

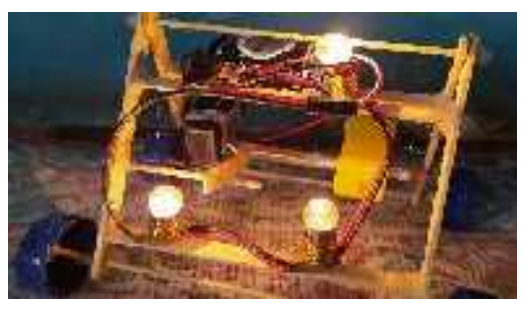

Figure 11

Pre-series of ETR media lamp The series of lamp after repairing The light of lamp after repairing

Subsequent improvements were made to the support the front media body that was connected to the dynamo. The cantilever was unable to withstand the weight of the front body of the media which was too heavy so that it was repaired twice.

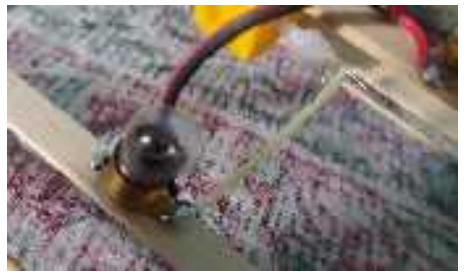

Figure 12

The first cantilever of ETR media

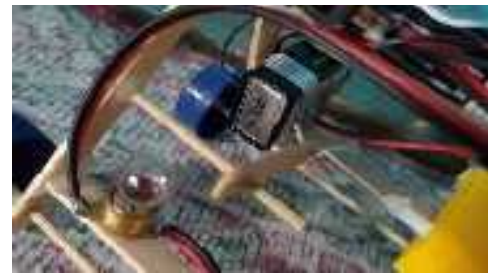

Figure 13

The cantilever of ETR media after the first repair

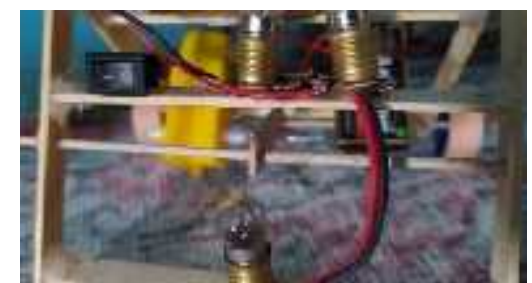

Figure 14

The first cantilever of ETR media after the second repair 'A

After improvements were made, the media were lack of progress. Placement of the components was very influential on the media such as the placement of the engine, electrical circuit, and framework of the ETR media framework itself. To make the media move, the placement of some components must be balanced both left and right side. That way the media will move forward well. If the placement was too heavy on the left or right side, the media would not advance forward but rotated to the placement.

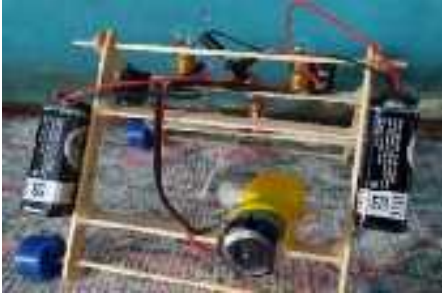

Figure 15. The first placement of engine component of ETR media

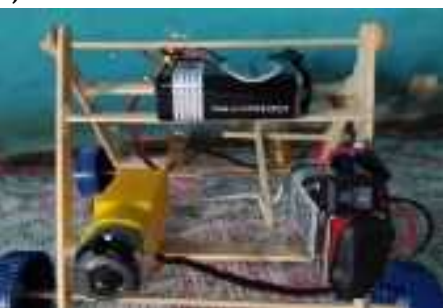

Figure 16

The placement of engine component of ETR media on the first repair

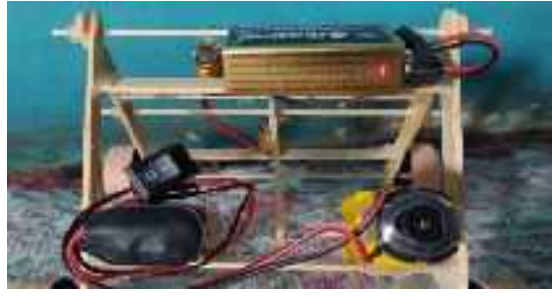

Figure 17

The second placement of engine component of ETR media 
After several repairs have been made, ETR media must be validated beforehand by several experts in their fields, especially instructional media experts. The purpose of the validation process was to determine the feasibility of the learning media design results. The results of this validation test showed that ETR media was worth testing in the learning process with consideration of improvements to some parts of ETR media.

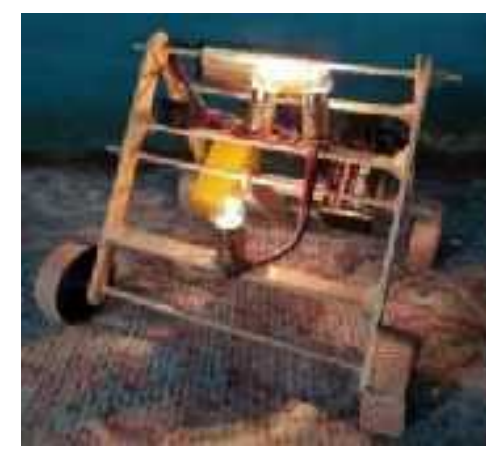

Figure 18

The ETR media product at the front side without lamp lit

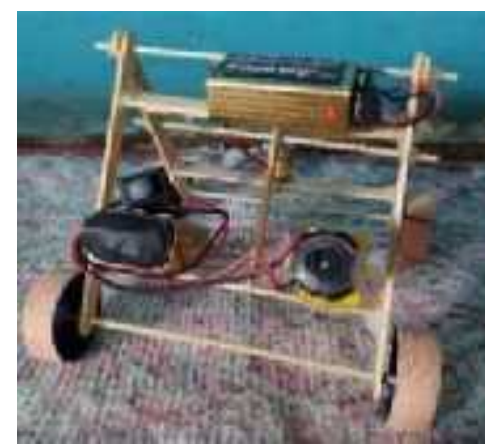

Figure 19

The ETR media product at the front side with lamp lit

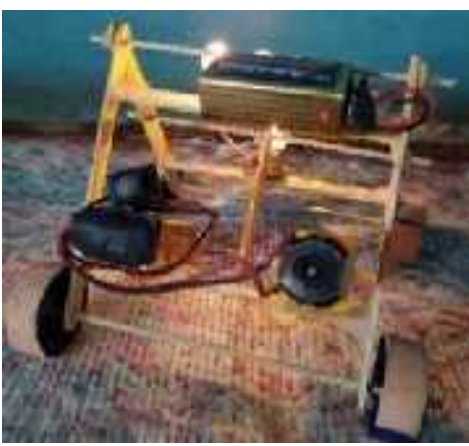

Figure 20

The ETR media product at backside without lamp lit

The improvement process was carried out based on the results of the FGD conducted with the learning device development team with the direction of several facilitators. The ETR media was repaired again to get well and optimal results. The process of improvements was conducted to see the feasibility of the product that was made based on its implementation on STEM conceptually learning, conformity with the mapping of basic competencies, and grade levels of students in elementary schools. After the ETR media went through a validation process through FGD activities, and improvements, the final product was obtained, ETR media for STEM learning based on 4C skills in elementary schools. ETR media was designed the sixth grade elementary school students. This media was able to contain learning materials for electrical components and their functions, speed, and explanatory texts on "Electricity, contextual discussion of" Changing Faces of the World "that integrated science, mathematics, and Indonesian subjects. ETR media products are expected to be one of the solutions and alternatives to support thematic learning in STEM learning. The use of instructional media in elementary schools needed to pay attention to the large benefits. The media can function thematically rather than division in certain subjects (Fristoni, 2013; Oktavianti \& Wiyanto, 2014).

Aspects of natural science subjects in the ETR media were found in the electrical circuits of lamps and car engines. When manufacturing lights and machinery, knowledge of electrical materials and electrical components were required. Aspects of mathematics were found in the measurement of the ETR media speed. Speed was calculated by comparing the distance traveled by the ETR media with the time taken to cover that distance. While aspects of Indonesian language were found in the presented text under the title "Electricity, Changing the Face of the World". In the text, it was explained about electrical material that can support student knowledge to make ETR media. Natural science subjects in the implementation of thematic learning can be used as a core of discussion which can be collaborated with other subjects (Noah, 2013).

In addition, the $21^{\text {st }}$ century skills were included in ETR media,, namely the $4 \mathrm{C}$ ability consisting of Critical Thinking, Creative, Collaboration, and Communication. The critical thinking aspect was found when students design and create ETR media. In making media, it requires the ability to think more deeply so that the media can be used successfully (Pratama \& Prastyaningrum, 2016; Amir, 2014). For example in making a series of lights and machines, students are required to think so that the installation process does not occur in the installation error so that the resulting circuit properly. Furthermore, creative, this aspect was found in the process of making design and make-up of media to make it more interesting. In the process of dressing the media, students are given the freedom to explore and be creative in dressing the ETR media. The creative achievement process can develop well supported by three prerequisites, namely adequate intellectual ability, motivation, and commitment to achieve excellence. These three prerequisites are internal encouragement of students (Fauziah, 2011). 
The collaboration aspect was found when students work together in making ETR media. The creation of ETR media was done in groups, with 4-5 students in one group. So, in making ETR media, students were required to collaborate so that the resulting media can be maximized. The collaborative learning environment challenges students to express and maintain their position, and generate their own ideas based on reflection. They can discuss in conveying ideas to their friends, exchanging different points of view, seeking clarification, and participating with high-level thinking such as managing, organizing, analyzing critically, solving problems, and creating new learning and deeper understanding (Zubaidah, 2018). Communication aspects were found when students present ETR media that has been made with a group of friends. In this aspect, students were required to be fluent in communicating with teachers and their peers. In this case students are required to use learning media as a source of learning. In the learning process, it is very necessary to have good communication between students so that students are able to exchange ideas well and can increase student knowledge (Marlina \& Jayanti, 2019). Especially in making this ETR media, student involvement is very calculated, because the creation of media is done by students with the guidance of the teacher. The $4 \mathrm{C}$ ability is very relevant to be applied to students in the $21^{\text {st }}$ century education era because it is able to make students more active in the learning process. And the use of ETR media can be an alternative in developing the ability of 4C students in elementary schools. Therefore, the involvement of students in the learning process is the main thing that must be achieved in the ability of the $4 \mathrm{C}$ which still requires some assistance and guidance and direction from the teacher (Kim, et al, 2019).

Pengembangan pembelajaran STEM umumnya dilakukan dengan menggunakan media yang sesuai. Penggunaan media ini digunakan sebagai sarana untuk membantu guru dalam membelajarkan siswa sehingga siswa dapat lebih memahani materi yang akan dipelajari. Media yang dikembangkan oleh Maula \& Fatmawati (2020) telah menumbuhkan motivasi belajar bagi peserta didik, melatih membaca dan pemahaman peserta didik, serta menumbuhkan inovasi bagi guru. Lalu media yang dikembangkan oleh Meilinda (2017) berupa media mock-up yang berhasil meningkatkan motivasi dan keaktifan siswa dalam pembelajaran sehingga pembelajaran yang dilaksanakan dapat bermakna bagi siswa. Begitu pula media yang dikembangkan oleh Falentina (2018) berupa Mobil Bertenaga Angin dapat menunjang dalam pelaksanaan pembelajaran STEM. Serta pengembangan media berupa mainan mobil mobilan lainnya seperti Mobil Bertenaga Pegas yang dikembangkan oleh Ramdhani (2019) yang berhasil dikembangkan sehingga dapat menunjang dalam proses pembelajaran STEM. Selain menunjang pembelajaran STEM, media tersebut juga dapat meningkatkan aktivitas siswa dalam pembelajaran dan mengasah kemampuan siswa untuk senantiasa berpikir kritis, kreatif, berkolaborasi dan berkomunikasi sehingga kemampuan 4C pada siswa dapat tercapai.

The development of STEM learning is generally done using appropriate media. The use of this media is used as a mean to assist teachers in teaching students so that students can better understand the material in learning. The media developed by Maula \& Fatmawati (2020) has fostered learning motivation for students, train in reading and students understanding, and fostered innovation for teachers. Then the media developed by Meilinda (2017) was in the form of mock-up media that succeeded in increasing students' motivation and activeness in learning so that the learning could be meaningful for students. Similarly, the media developed by Falentina (2018) in the form of a Wind Powered Car can support the implementation of STEM learning. As well as the development of media in the form of other toy car such as Spring Powered Cars developed by Ramdhani (2019) which were successfully developed so that they can support the STEM learning process. Besides supporting STEM learning, the media can also increase student activities in learning and hone students' ability to always think critically, creatively, collaborate, and communicate so that the $4 \mathrm{C}$ ability of students can be achieved.

\section{Conclusion}

Media Electrical Tandem Roller (ETR) telah dikembangkan untuk pembelajaran STEM berdasarkan kemampuan 4C di sekolah dasar sebagai upaya untuk melengkapi kekurangan ketersediaan media pembelajaran, sifat media ini dapat menunjang pembelajaran tematik kurikulum 2013 di kelas VI sekolah dasar. Media pembelajaran ini dilakukan untuk dalam rangka memberikan contoh yang nyata dalam memberikan solusi permasalahan yang terjadi dalam pembelajaran tematik di sekolah dasar. Media tersebut dirancang melalui tahapan FGD dengan memperhatikan aspek-aspek penting yang dituangkan berdasarkan prinsip desain (design principle) yang digunakan. Produk akhir berupa media yang diberi nama "Electrical Tandem Roller (ETR)". Karena masih dalam tataran 
pengembangan secara konseptual, disarankan untuk melakukan pengujian lapangan terhadap media ETR ini untuk melihat keefektifan penggunaan beserta perangkat pembelajaran lain dalam tim pembelajaran STEM. Uji lapangan terhadap media ETR ini dapat secara nyata berpeluang ditemukan kekurangan dan kelebihan baik dilihat dari segi guru maupun siswa. Selanjutnya, media ETR diharapkan dapat menjadi bahan referensi bagi guru dalam melaksanakan proses pembelajaran terutama pada pembelajaran STEM dengan mengintegrasikan mata pelajaran IPA, Matematika dan Bahasa Indonesia pada topik rangkaian listrik. Implemetasi pembelajaran STEM dengan media ETR digunakan untuk menarik minat belajar siswa dengan merujuk kepada peningkatkan kemampuan $4 C$ pada siswa.

Media Electrical Tandem Roller (ETR) has been developed for STEM learning based on the ability of 4C in elementary schools as an effort to complete the lack of learning media availability. The nature of this media can support thematic learning of the 2013 curriculum in the fifth grade elementary schools. This learning media is done to provide concrete examples in providing solutions to problems that occur in thematic learning of elementary schools. The media are designed through FGD stages by paying attention to important aspects outlined based on the design principles used. The final product is a media named "Electrical Tandem Roller (ETR)". Because it is still at the conceptual level of development, it is recommended to conduct a field test of this ETR media to see the effectiveness of the use along with other learning tools in the STEM learning team. Field testing of the ETR media can significantly reveal the advantages and disadvantages both in terms of teachers and students. Furthermore, ETR media is expected to be a reference material for teachers in implementing the learning process, especially in STEM learning by integrating science, mathematics and Indonesian subjects on the topic of electrical circuits. The implementation of STEM learning with ETR media is used to attract students' learning interest by referring to improve the $4 \mathrm{C}$ ability of students.

\section{References}

Afiyanti, Y. (2008). Focus Group Discussion (Diskusi Kelompok Terfokus) sebagai Metode Pengumpulan Data Penelitian Kualitatif. Jurnal Keperawatan Indonesia, Volume 12, No. 1, Maret 2008; hal 58-62.

Agung, Anak Agung Gede. (2014). Metodologi Penelitian Pendidikan. Malang: Aditya Media Publishing.

Amir, A. (2014). Pembelajaran matematika SD dengan menggunakan media manipulatif. In Forum Paedagogik (Vol. 6, No. 01).

Baral, S et al. (2016). Focus Group Discussion. Bhotechaur, Sindhupalchowk. HERD Publication

Bareen, L, R. (2006). A Practical Guide to Focus-Group Research. Journal of Geography in Higher Education. https://doi.org/10.1080/03098260600927575

Cunningham, C. M. (2018). Engineering in Elementary STEM Education (Curriculum Design, Instruction, Learning, and Assesment). New York, United States of America: Teachers College.

English, L. D., \& King, D. T. (2015). STEM learning through engineering design: fourth-grade students' investigations in aerospace. International Journal of STEM Education, 2(1). https://doi.org/10.1186/s40594-015-0027-7.

Falentina, C. T. (2018). Mobil Bertenaga Angin: Media Berbasis STEM untuk Siswa Kelas IV Sekolah Dasar. Pedadidaktika: Jurnal Ilmiah Pendidikan Guru Sekolah Dasar, 5(3), 152-162.

Fauziah, Y. N. (2011). Analisis kemampuan guru dalam mengembangkan keterampilan berpikir kreatif siswa Sekolah Dasar kelas V pada pembelajaran Ilmu Pengetahuan Alam.Jurnal Edisi Khusus, 1(1), 98-106.

Firman, H. (2015). Pendidikan Sains Berbasis STEM: Konsep, Pengembangan, dan Peranan Riset Pascasarjana. Bogor: Pascasarjana Universitas Pakuan.

Fristoni, M. (2013). Penggunaan Media Papan Flanel Untuk Meningkatkan Proses Pembelajaran Tematik Pada Siswa Sekolah Dasar. Jurnal Penelitian Pendidikan Guru Sekolah Dasar, 1(2), 111.

Glynn P, Shanahan M and Duggan D. (2015). Focus groups. Available from: https://www.slideshare. net/johnglynn940/focus-groups-presentation. 
Griffin, P., \& Care, E. (2015). Assessment and Teaching of 21st Century Skills: Methods and Approach. Dodrecht: Springer Business Media.

Griffin, P., McGaw, B., \& Care, E, (Ed). (2012). Assessment and Teaching of 21st Century Skills. Germany: Springer Science + Business Media.

Hernawan, A.H. 2007. Media Pembelajaran SD. Bandung: UPI Press.

Indrizal, E. (2014). DISKUSI KELOMPOK TERARAH Focus Group Discussion (FGD) (Prinsip-Prinsip dan Langkah Pelaksanaan Lapangan). FISIP Universitas Andalas, Padang. Hlm. 75-82.

Kadir, A., \& Asrohah, H. (2015). Pembelajaran Tematik. Depok: Rajawali Pers PT Raja Grafindo Persada.

Kim, S., Raza, M., \& Seidman, E. (2019). Improving 21st-century teaching skills: The key to effective 21st-century learners. Research in Comparative and International Education, 14 (1), 99-117. https://doi.org/10.1177/1745499919829214

Majid, A. (2014). Pembelajaran Tematik Terpadu. Bandung: PT Remaja Rosdakarya.

Marlina, W., \& Jayanti, D. (2019). 4C Dalam Pembelajaran Matematika Untuk Menghadapi Era Revolusi Industri 4.0. PROSIDING SENDIKA, 5(1).

Maula, N. R., \& Fatmawati, L. (2020). Pengembangan Media Pembelajaran Kayaku (Kayanya Alam Negeriku) Berbasis STEM Kelas IV Sekolah Dasar. Jurnal Ilmiah Sekolah Dasar, 4(1), 100-109.

Meilinda, I. (2017). Media Mock-up pada Pembelajaran Tematik Berbasis Outdoor Learning di Sekolah Dasar. Pedadidaktika: Jurnal Ilmiah Pendidikan Guru Sekolah Dasar, 4(2), 139-148.

Mudlofir, A., \& Rusydiyah, E. F. (2017). Desain Pembelajaran Inovatif Dari Teori ke Praktik. Depok: Rajawali Pers PT Raja Grafindo Persada.

Nuh, M. (2013). Kurikulum 2013. Sumber: http://www. kemdiknas. go. id.

Nurlenasari, N., Lidinillah, D., Nugraha, A., \& Hamdu, G. (2019). Assessing 21 st century skills of fourthgrade student in STEM learning. IOP Conf. Series: Jurnal of Physics, 1-7. https://doi.org/10.1088/1742-6596/1318/1/012058

Omar, D. (2018). Focus Group Discussion in Built Environment Qualitative Research Practice. IOP Conference Series: Earth and Environmental Science. https://doi.org/10.1088/1755$\underline{1315 / 117 / 1 / 012050}$

Oktavianti, R., \& Wiyanto, A. (2014). Pengembangan Media Gayanghetum (Figure Wayang Hewan dan Tumbuhan) dalam Pembelajaran Tematik Terintegrasi Kelas IV SD. Mimbar Sekolah Dasar, 1(1), 65-70.

Pambudi, B., Efendi, R. B., Novianti, L. A., Novitasari, D., \& Ngazizah, N. (2018). Pengembangan Alat Peraga IPA dari Barang Bekas untuk Meningkatkan Motivasi Belajar dan Pemahaman Siswa Sekolah Dasar. Indonesian Journal of Primary Education 2(2), 2-6.

Pimthong, P., \& Williams, J. (2018). Preservice teachers' understanding of STEM education. Kasetsart Journal of Social Sciences, 1-7. https://doi.org/10.1016/j.kjss.2018.07.017.

Pratama, H., \& Prastyaningrum, I. (2016). Pengaruh model pembelajaran project based learning berbantuan media pembelajaran pembangkit listrik tenaga mikrohidro terhadap kemampuan berpikir kritis. Jurnal Penelitian Fisika Dan Aplikasinya (JPFA), 6(2), 44-50.

Ramdhani, R. A. (2019). Pengembangan Media Mobil Bertenaga Pegas Berbasis STEM untuk Mencapai Kemampuan 4C di Sekolah Dasar. JPII: Jurnal Pendidikan IPA Indonesia.

Sanaky, H. (2011). Media Pembelajaran. Yogyakarta: Kaukaba.

Torlakson, T. (2014). INNOVATE: A Blueprint for Science, Technology, Engineering, and Mathematics in California Public Education. California: Californians Dedicated to Education Foundation.

Wijayanti, Siundah. (2018). Implementasi Class Got Talent Berbantuan Minibook dalam Pembelajaran IPA untuk Meningkatkan Keterampilan Proses Abad 21 Peserta didik. Jurnal Pembelajaran Sains. ISSN: 2527-9157.

Zubaidah, S. (2018). Mengenal 4C: Learning and Innovation Skills untuk Menghadapi Era Revolusi Industri 4.0. In 2nd Science Education National Conference (pp. 1-18). 